\title{
SERO-PREVALENCE OF RESPIRATORY SYNCYTIAL VIRUS INFECTION IN CHILDREN (0-5YEARS) ATTENDING INSTITUTE OF CHILD HEALTH BANZAZZAU ZARIA KADUNA STATE
}

\author{
${ }^{1}$ Sulaiman, M. A., ${ }^{2}$ Musa Hassan Muhammad and ${ }^{1}$ Jane, F. \\ ${ }^{1}$ Department of Microbiology, Faculty of Life Sciences, Ahmadu Bello University, Zaria. \\ ${ }^{2}$ Department of Microbiology, Federal University, Dutse \\ *Correspondence author: maimunaabdulkadir@yahoo.com
}

\begin{abstract}
Serological survey was carried out among children attending Institute of Child Health (ICH) Banzazzau Zaria Kaduna, State, to determine the prevalence of Respiratory Syncytial Virus IgM antibodies. Ninety-one blood samples of children aged 0-5years were collected in one outpatient clinic of Ahmadu Bello University Teaching Hospital Zaria (ICH Banzazzau). Respiratory syncytial virus IgM antibody level was measured using commercial ELISA kit obtained from DIAGNOSTIC AUTOMATION, INC. Of the ninety-one blood samples collected and tested, 43(47.3\%) were seropositive for Respiratory Syncytial Virus. There was male predominance, with $23(25.3 \%)$ being positive compared in females 20 (22.0\%) although, the difference was not statistically significant $(P$ value $>0.05)$. The seroprevalence was highest $(15.4 \%)$ among infants 0 -1year and lowest (5.5\%) among 3 years old children..The association between RSV infection and respiratory symptoms was not statistically significant. Every child who showed seropositivity with the Respiratory Syncytial Virus had fever and no child without a fever was diagnosed positive with the virus. This study has revealed that children aged 0-5 years have high prevalence of RSV Infection in Zaria, and therefore, highlighting the need for the younger age group to be targeted for prevention programme against RSV infection.

Key words: Serology, Banzazzau, Zaria, Kaduna state, blood samples, IgM, antibodies, Respirtory Syncitial Virus (RSV).
\end{abstract}

\section{INTRODUCTION}

Human Respiratory Syncytial Virus (RSV) is an RNA virus that causes respiratory tract infections in children, it was first isolated in 1956 from a laboratory chimpanzee with a respiratory illness and was later discovered to be of human origin (Collins et al., 2008). RSV consists of two antigenic subtypes, A and B. Subtype B is characterized as the asymptomatic strains that of which the majority of individuals experiences. The more severe illnesses and which usually predominate during outbreaks are associated with subtype A strains (Oliveira et al., 2008). RSV was determined to be the leading cause of lower respiratory tract infections particularly in young infants (Oliveira et al., 2008). The severity of the disease is very diverse ranging from mild cold symptoms to severe and life-threatening. It's the leading cause of pneumonia and bronchiolitis in infants (Opavsky, 1995). It may cause mortality or morbidity in the elderly as well as immunodeficient individuals. It is the most common pathogen leading to hospitalization in young children up to the age of 5 . Approximately two thirds of infants are infected with RSV within their first year and $90 \%$ have been infected by the age of 2 (Collins et al., 2008).

RSV is an enveloped, non-segmented, negativestranded RNA virus and a member of the Paramyxoviridae family (Robertson et al., 2004). Two subtypes, A and B, are present in most outbreaks. Subtype A usually causes more severe disease (Gilca et al., 2006). The dominant strains shift each year, which may account for frequent re-infections (Shier and Badr, 2000). The incubation period ranges from two to eight days; viral shedding ranges from three to eight days, although it may continue for up to four weeks in young infants (Pickering et al., 2009).

An RSV infection begins with replication of the virus in the nasopharynx. The virus spreads to the small bronchiolar epithelium lining the small airways within the lungs, and a lower respiratory tract infection can begin in one to three days. If a lower respiratory tract infection occurs, it causes edema, increased mucus production, and eventual necrosis and regeneration of these epithelial cells. This leads to small airway obstruction, air trapping, and increased airway resistance (Mohammed, 2009).

Respiratory Syncytial Virus is spread through person to person contact by infected respiratory secretions. It requires the close contact of infected individuals, contact with infected nasal secretions, or contamination of hands or objects which have been introduced to such secretions. Outbreaks of the disease occur yearly at particular seasons, which usually last up to 5 months (McIntosh, 1997). Epidemics usually occur in the late fall, winter or spring seasons, with most outbreaks in February or March (Collins et al., 2008) RSV is commonly acquired by patients who are hospitalized and the likelihood of RSV infection increases with the duration of the stay. The hospital staff plays a major role in the spread of RSV infection. To reduce the risk of infection precautions must be in effect such as hand washing (Akinloye et al., 2011).

Very few researches have reported the involvement of RSV. This research seeks to establish if RSV is significant, and if its, to what extent. 
Bajopas Volume 10 Number 2 December, 2017

Therefore, the objectives of this study were to determine the seroprevalence, the demographic and risk factors of RSV in children attending $\mathrm{ICH}$ Banzazzau, Zaria.

\section{MATERIALS AND METHODS \\ Study Design}

This research work is a cross sectional study. Children attending Institute of Child Health (ICH) Banzzazau Zaria from 0-5years of age were recruited for the study.

\section{Area of Study}

The study area comprises 1 hospital in Zaria local government area of Kaduna state. Zaria local government has a population of about 408,198 inhabitants (Stilwell, 2008). It is located on longitude $8^{0}$ and latitude $9^{0}$. The hospital is Institute of child Health (ICH) Banzazzau.

\section{Questionnaire}

Information was collected by means of specially designed questionnaire for this study. The informants were the parents or adult care givers of the children under study. The Age, sex and health status of the child was enquired for and filled into appropriate section of the questionnaire (appendix I)

\section{Sample Collection and Processing}

The samples were collected from children whose parents/guardians consented. Dry sterile plastic syringe ( $2 \mathrm{ml}$ capacity) with $23 \mathrm{SWG}$ needle attached to was used for blood collection. Blood was collected by applying soft tubing tourniquet on the arm of the patient to enable the veins seen and felt. The puncture site was cleaned using methylated spirit and allowed to air dry. The needle was inserted to the selected straight vein with the bevel of the needle directed upward in the line of the vein. Steadily the plunger of the syringe was withdrawn until $2 \mathrm{mls}$ of blood was obtained. The tourniquet was loosed and the needle was removed from the punctured vein. Pressure was applied to the punctured site to secure homeostasis. The needle was removed from the syringe and the blood was transferred to a clean dry plain specimen bottle and labeled. The used syringes and needles were disposed appropriately. The blood samples were centrifuged at 1500 revolution per minute for five minutes (1500 rpm/min for $5 \mathrm{~min}$ ) and the serum collected into clean dry plain specimen Pasteur pipettes and stored at $-20^{\circ} \mathrm{C}$ until needed for analysis (Cheesbrough, 2006). All tests were carried out using Enzyme linked Immunosorbent Assay (RSV IgM antibody against the RSV). Manufacture's instruction were duly followed. The optical density (OD) values were read at $450 \mathrm{~nm}$, using ELISA micro plate Reader. The kit has $100 \%$ specificity and $86 \%$ sensitivity.

\section{Procedures}

Samples were diluted appropriately using sample diluent $(1: 100 \mu l)$. Microliter wells for the cut-off standard, controls (negative and positive), samples as well as substrate blank were labelled. About $100 \mu l$ each of diluted samples and ready-to-use standards and controls respectively were pipetted into the appropriate wells. The first well was left empty as blank, mixed by gentle shaking and incubated for one hour at room temperature. The wells were emptied after incubation and washing buffer was added into the wells and emptied. This procedure was repeated three times. The rest of the washing solution was afterwards removed by gentle tapping of the

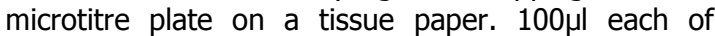
ready-to-use conjugate were added into the wells. This time also the substrate blank was left empty. The plates were incubated at room temperature for 30 minutes, the same procedure for washing was followed, and $100 \mu \mathrm{l}$ each of the ready-to-use substrate was pipetted into the wells. This time the substrate was pipetted into the blank, incubated at room temperature for 20 minutes. About $100 \mu \mathrm{l}$ of stop solution was finally pipetted into the wells to terminate the substrate reaction, after thorough mixing and wiping the bottom of the plate, perform the reading, of the absorption at $450 \mathrm{~nm}$ was made using ELISA READER MACHINE

\section{RESULTS}

Of the ninety-one blood samples tested for the presence of Respiratory Syncytial Virus (RSV) antibody (IgM), a total of $43(47.3 \%)$ samples were seropositive for the RSV antibody (IgM).

The prevalence of RSV antibody (IgM) in relation to sex was found to be $23(25.3 \%)$ for the males and $20(22.0 \%)$ for the female. However, the difference in Seropositivity observed across the sex showed no statistical significant $\left(P\right.$ value $\left.=0.157 ; X^{2}=0.505\right)$ as shown in Table 1.

Table 1: Prevalence of RSV IgM antibody in relation to sex in children.

\begin{tabular}{cccc}
\hline Sex & Positive(\%) & Negative(\%) & Total \\
\hline Male & $23(25.3)$ & $29(31.9)$ & 52 \\
Female & $20(22.0)$ & $19(20.8)$ & 39 \\
Total & $43(47.3)$ & $48(52.7)$ & 91 \\
\hline
\end{tabular}

P.value $=0.157 \quad \times 2=0.505$

$P<=0.05$ is statistically significant at $95 \%$ confidence interval 
Table 2 represents the Age specific seroprevalence of RSV antibody (IgM) in children receiving health care at ICH Banzauzzau. The highest prevalence of the respiratory syncytial virus was found to be within the age grade of $0-1$ year who represent a prevalence of $15.4 \%$ (14 children), this was closely followed by the age grade of 2 years who represent a total prevalence of $12.1 \%$ (11 children) the least prevalence was found to be within the age grade of 3years with a standing prevalence of $5.5 \%$ ( 5 children). Regression analysis showed that the variation across the age grades was not statistically significant at ( $P$.value $=$ $\left.0.878, R^{2}=0.616\right)$.

Table 2: Prevalence of RSV IgM antibody according to age of children

\begin{tabular}{cccc}
\multicolumn{5}{c}{ RSV_Status } & Total \\
Age & Positive (\%) & Negative(\%) & 29 \\
\hline $0-1$ yrs & $14(15.4)$ & $15(16.5)$ & 19 \\
2 yrs & $11(12.1)$ & $8(8.8)$ & 13 \\
3yrs & $5(5.5)$ & $8(8.8)$ & 14 \\
4yrs & $6(6.6)$ & $8(8.8)$ & 16 \\
$5 y r s$ & $7(7.7)$ & $9(9.8)$ & 91 \\
Total & $43(47.3)$ & $48(52.7)$ & \\
\hline P. value $=0.878, R^{2}=0.616 \mathrm{P}>=0.05$ is statistically significant at 95\% confidence interval
\end{tabular}

The relationship between some respiratory symptoms and fever with the occurrence of the respiratory syncytial virus was reported. A higher prevalence of RSV was found among children with cough (26.4\%) than those without cough (20.9\%). Likewise, a higher prevalence of RSV was found in children with catarrh $(27.5 \%)$ than those without catarrh (19.8\%). However, all the seropositive patients had fever (Table 3).

Table 3: Relationship between some risk/symptomatic factors and the occurrence of RSV among children attending ICH Banzauzzau

\begin{tabular}{lllll}
\hline Symptoms & No. tested & No. positive & P value & Chi square \\
\hline Cough & 42 & 24 & 0.08 & 3.06 \\
Yes & 49 & 19 & & \\
No & 46 & 25 & & \\
$\frac{\text { Catarrh }}{\text { Yes }}$ & 45 & 18 & 0.17 & 1.88 \\
No & 43 & 47 & & \\
Fever & 0 & 1 & 0.34 & 0.90 \\
Yes & No & & & \\
\hline
\end{tabular}

\section{DISCUSSION}

Respiratory syncytial virus (RSV) is the single most important cause of viral lower respiratory tract infection during infancy and early childhood worldwide (McNamara and Smyth 2002 as such IgM antibody was measured to determine the proportion of seropositive and the level of the antibody with respect to age, gender and the presence of respiratory symptoms.

It was found in this study that $43(47.3 \%)$ of the subjects were seropositive for RSV IgM antibody. This is in contrast with the study of Mohammed, (2009) who reported $93.1 \%$. However, IgG was the antibody considered in his study. In assessing the sex specific prevalence of RSV antibody, seropositivity was observed to be higher in males $(25.3 \%)$ than in females $(22.0 \%)$ although the difference was not statistically significant. This agree with the previous study of Shier and Badr (2000) who recorded increase percentage of male RSV positive cases than female cases.

The highest prevalence of the Respiratory Syncytial Virus was found within the age group of $0-1$ year giving a prevalence of $15.4 \%$. This agrees with the previous work of Mohammed (2009) who reported a prevalence of $11.6 \%$ and was in contrast with the work of Robertson et al., (2004) who recorded a prevalence of $36 \%$ among children below 1year. The higher prevalence in this group may be associated with their underdeveloped immune system. This was closely followed by children within the age of 2 years with a prevalence of $12.1 \%$. The least prevalence $(5.5 \%)$ was found among children within the age of 3. For the ages of 4 and 5 , with the prevalence of $(6.6 \%)$ and $(7.7 \%)$ respectively, which suggests recurrent infection since there is no permanent immunity to infection with the virus. 
A higher prevalence of RSV was found among children with cough $(26.4 \%)$ than those without cough (20.9\%). Likewise, a higher prevalence of RSV was found in children with catarrh $(27.5 \%)$ than those without catarrh (19.8\%). Although the association between RSV infections with these respiratory symptoms is not statistically significant. This could be due to the fact that other microbial agents may be responsible for these symptom.

The result also revealed that every child who showed seropositivity with the Respiratory Syncytial Virus had a fever and no child without a fever was diagnosed positive with the virus. This agrees with the study of (Almasri et al., 2013) who recorded fever as the most common symptoms in patients with RSV infection.

\section{CONCLUSION}

At the end of this study RSV IgM antibodies were detected in children attending ICH Banzazzau Zaria with the seroprevalence of $47.3 \%$, with high

\section{REFERENCES}

Akinloye M.O., Ronkko E., Savolanien-Kopra C., Ziegier T., Iwalokun, B.A., Deji-Agboola, M., Oluwadun, A., Roivainen, M., Adu, F.D. and Hovi, T. (2011). Specific viruses detected in Nigerian children associated with acute respiratory disease. Journal of Tropical of Medicine,6:902-986.

Almasri M., Papa, A., Souliou, E., Haidopoulou, K. and Eboriadou M. (2013). Respiratory Syncytial Virus infection in hospitalized children older than 2 years with Community-acquired pneumonia. Hippokratia,17(2):146-149

Cheesbrough M. (2006). District Laboratory Practice in Tropical Countries. Second edition (part 2). Cambridge University Press, Cambridge, New York, United State of America,248-266.

Collins L., Peter, B. and Graham, S. (2008). Viral and Host Factors in Human Respiratory Syncytial Virus Pathogenesis. Journal of Virology,82:2040-2055.

Gilca, R., DeSerres, G. and Tremblay, M. (2006). Distribution and clinical impact of human respiratory syncytial virus genotypes in hospitalized children over 2 winter seasons. Journal of Infectious Disease, 193(1):54-58.

McIntosh, K. (1997). Respiratory Syncytial Virus. In: Evans, A., Kaslow. R., (Ed). Viral Infections in Humans: Epidemiology and control. $4^{\text {th }}$ edition. New York: Plenum:691 - 705.

McNarama P.S. and Smyth, R.L. (2002). The Pathogenesis of Respiratory Syncytial Virus disease in childhood. British Medical Bulletin, 61:13-28

Mohammed, A.A. (2009) Human Respiratory Syncytial Virus Infection among Children 1-5 years in Zaria Kaduna State. Unpublised M.Sc. thesis prevalence in males $(25.3 \%)$ than females $(22.0 \%)$, particularly, within the age group of 0 -1year (15.4\%). High prevalence of RSV was observed among children with cough $(26.4 \%)$ and catarrh $(27.5 \%)$ and all the seropositive children had fever.

\section{RECOMMENDATION}

In view of the high prevalence of RSV IgM antibody observed in this study, so proper awareness programmes should be setup to educate hospital staff, parents/guardians and patient's families about RSV, emphasize on maintaining good hand washing procedures. Use contact isolation for patients who have RSV with the view to reduce the spread of the virus.

Conflict of Interest: None

CONTRIBUTION OF AUTHORS

M. A. Sulaiman: designed the study and supervised the work.

Musa Muhammad Hassan: Results analysis

J. Francis: Samples collection and Processing.

Department of Microbiology, Ahmadu Bello University, Zaria, Nigeria.

Oliveira T.F.M., Freitas, G.R.O., Ribeiro, L.Z.G., Yokosawa, J., Siqueira, M.M. and Portes, S.A.R.(2008). Prevalence and clinical aspects of respiratory syncytial virus $A$ and $B$ groups in children seen at Hospital de Clínicas of Uberlândia, MG, Brazil. Oswaldo Cruz,103: 417-422.

Opavsky, M. A., Stevens, D. and Wang, E.E. (1995). Testing models predicting severity of respiratory syncytial virus infection in the PICNIC RSV Database. Archieves of pediatrics Adolescense Medicine,149:12171220.

Pickering, L.K., Baker, C.J., Kimberlin, D.W. and Long, S.S.(2009). Report of the Committee on Infectious Diseases. 28th ed. Elk Grove Village, Ill. American Academy of Pediatrics,563-608.

Robertson, S.E., Roca, A., Alonso, P., Simoes, E.A, Kartasasmita, C.B., Olaleye, D.O., Odaibo, G.N., Collinson, M., Venter, M., Zhu, Y. and Wright, P.F.(2004). Respiratory Syncytial Virus infection, denominator-based studies in Indonesia, Mozambique, Nigeria and South Africa. Bulletin of World Health Organization,82:914-922.

Shier, M.K, and Badr, M.A. (2000). RSV infection in patients Vising King Khalid University Hospital. America Journal of Respiratory Critical Care Medicine,161(5):1501-1507.

Stilwell, S. (2008). Power, Honour and Shame: The Ideology of Royal Slavery in the Sokoto Caliphate. Africa: Journal of the International African Institute, 70 (3): 394-421. 